\title{
Fish Health Management Considerations in Recirculating Aquaculture systems - Part 3: General Recommendations and Problem-Solving Approaches ${ }^{1}$
}

Roy P.E. Yanong ${ }^{2}$

\section{Introduction}

Both the popularity and use of recirculating systems have increased, and these systems are now commonly used in aquaculture facilities, wholesale and retail tropical fish facilities, and public aquaria.

This circular is Part 3 of a three-part series dealing with fish health management in recirculating aquaculture systems. This document provides general recommendations for choosing, setting up, and running a system, as well as some problem-solving approaches to help maintain a well-managed system - regardless of its purpose. This basic information should assist the beginner or intermediate-level aquaculturist interested in maintaining healthy fish in recirculating systems.

A good understanding of preventative medicine and determination of the primary use or type of system is essential for success, and these topics are covered in Part 1 of the series. Part 2 provides an introduction to pathogens and pathogen control in recirculating systems. This series is a starting point for anyone considering installing or currently using a recirculating system.
We recommend to anyone considering installing or currently using a recirculating system that they read each of these documents.

\section{General Recommendations}

Well-designed and well-run recirculating systems require a good deal of planning and maintenance. The steps required for proper development and execution of a recirculating system can be divided into a design phase, a start up phase, and a maintenance phase. Each step or phase has specific requirements described below. Biosecurity measures should be established and followed for each phase. More specific biosecurity recommendations are also described.

Unfortunately, no matter how well a system is managed problems will occur. Suggested troubleshooting methods are covered in the last section of this circular, "Problem-Solving Approaches."

1. This document is Circular 122, one of a series from the Department of Fisheries and Aquatic Sciences, Florida Cooperative Extension Service, Institute of Food and Agricultural Sciences, University of Florida. Original publication date December 2003. Visit the EDIS Web Site at http://edis.ifas.ufl.edu.

2. Roy P.E. Yanong, Assistant Professor, Tropical Aquaculture Laboratory, Ruskin FL 33570, Department of Fisheries and Aquatic Sciences, Florida Cooperative Extension Service, Institute of Food and Agricultural Sciences, University of Florida, Gainesville, FL 32611.

The Institute of Food and Agricultural Sciences is an equal opportunity/affirmative action employer authorized to provide research, educational information and other services only to individuals and institutions that function without regard to race, color, sex, age, handicap, or national origin. For information on obtaining other extension publications, contact your county Cooperative Extension Service office. Florida Cooperative

Extension Service/Institute of Food and Agricultural Sciences/University of Florida/Christine Taylor Waddill, Dean. 


\section{Phase 1: Design}

Before making any monetary commitment, the owner should seriously consider if a recirculating system is the best system for his/her needs and budget. The owner must also be prepared and willing to learn all the additional skills required in order to maintain such a system properly. A good understanding of water quality is essential, as is knowledge of pathogens and their control (see Part 2 of this series). Prior to purchasing or building a system, consult with an aquaculture specialist or an expert on recirculating systems.

All important factors (see Part 1 of this series), including species biology and requirements, life stage, system purpose, density, expected feeding rate, capital costs, labor costs, maintenance costs, ability to operate each vat or tank independently of the rest of the system, desired water quality, and required or desired equipment (pumps, filters, tanks, sterilization systems, and backups or redundancy for important components such as filters and pumps) should be taken into account during the design phase. Plans should also lay out maintenance protocols, including weekend and holiday maintenance and monitoring. Protocols for emergency situations, such as power outages, water pump or compressor (air pump) failures, major temperature fluctuations (such as freezes during the winter that may affect poorly insulated buildings), accidental overdose of treatment chemicals or accidental use of chlorine or other disinfectants in a system with fish, should also be readily available.

\section{Phase 2: Start Up}

Once the system has been built, it should be operated without fish for a minimum of two to four days to make sure that there are no leaks, that flows are adequate, and no other significant flaws exist. Because of the potential toxicity of some glues and other building materials, the water used in this test period should be exchanged at least once prior to the introduction of any fish. The system should also be monitored for potential supersaturation of gases (primarily of nitrogen gas) entering through leaks on the intake side of each pump). Evidence of supersaturation incudes numerous visible air bubbles on tank walls or in the water column. Various tests or meters can also be used to detect supersaturation.

New recirculating systems typically have no bacteria established in the biological filter (biofilter) and, therefore, they require three to eight weeks, or longer, to become cycled (i.e., have enough bacteria established in the biofilter to reduce ammonia and nitrite to non-toxic levels). The time required to cycle a biofilter will depend on the fish load, the type of food fed to the fish and their feeding rate, as well as the $\mathrm{pH}$, alkalinity, and temperature of the water.

There are several ways to cycle a system. The best results typically come from a combination of:

- gradually increasing the number of fish in the system (using the species that will eventually be held in that system); water changes may be necessary if ammonia and nitrite concentrations are too high;

- using hardy species (such as black tetras or zebra danios in freshwater and damselfish or mollies in salt water) in slowly increasing numbers prior to stocking with the intended species;

- using biofilter media or water from an established system with a history of few to no problems with fish health;

- using liquid ammonia at low levels, at approximately $2-3 \mathrm{mg} / \mathrm{L}$ total ammonia nitrogen (TAN), to feed the establishing bacteria population prior to introduction of any fish; or

- using active biofilter bacterial cultures from reputable sources.

Regardless of the approach, ammonia, nitrite, $\mathrm{pH}$, and alkalinity should be measured on a daily basis to determine when the ammonia and nitrite levels have peaked and then dropped to non-toxic levels. Dissolved oxygen (DO) should also be monitored at least several times a day in heavily stocked or heavily fed systems. Some systems have continuous dissolved oxygen-sensing meters in place. Oxygen consumption by the fish typically increases immediately during and after feeding. 
Bicarbonate and carbonate (alkalinity) are essential for the biofilter to function properly. In heavily stocked and fed systems, alkalinity and $\mathrm{pH}$ levels should be monitored at least twice a week to avoid sudden drops in $\mathrm{pH}$, which can lead to the biofilter failing. Less frequent monitoring (once a week or every two weeks) may suffice for less intensively stocked systems.

If warranted, other water quality parameters may require monitoring, depending upon the type of system, stocking and feeding rates, species of fish kept, and treatments currently in use. Some of these parameters include the hardness (an important parameter for spawning, hatching, and rearing larvae and fry), salinity, calcium, nitrate, copper (such as during marine fish parasite treatments), conductivity, oxidation reduction potential (redox or ORP as an estimate of ozone), and bacterial load (approximate concentration of bacteria in the water).

\section{Phase 3: Maintenance}

General system protocols should be readily available (such as posted on a wall, written in a notebook or kept on a computer), explained carefully to all relevant employees, and followed. These protocols should include measuring and recording water quality parameters (e.g., ammonia, nitrite, $\mathrm{pH}$, alkalinity, DO, temperature, hardness, and salinity), general system checks (examination of pumps, filters and tanks or vats for any obvious problems), techniques for siphoning, schedules and methods for changing out water, chemical additions, filtration backwashes, and other general maintenance procedures (for example, UV-bulb replacement, UV-sleeve examination, and ozone or redox measurements).

Water quality parameters should be kept as stable as possible, ideally with undetectable levels of ammonia or nitrite. Many freshwater aquaculturists maintain salt $(\mathrm{NaCl})$ at levels of $1-3 \mathrm{~g} / \mathrm{L}(1-3$ ppt or $0.1-0.3 \%$ ) in their system. This level of salt aids in reducing parasite loads, prevents brown blood disease caused by excess nitrite, and assists in reducing osmoregulatory stresses (see UF/IFAS Fact Sheet VM-86 The Use of Salt in Aquaculture).
Fish behavior and feeding should also be monitored and recorded. Any change in behavior or feeding is a signal of potential water quality problems or other fish health issues. Mortalities (deaths) should also be recorded daily. The number and percentage of fish that die during a disease outbreak often helps narrow down potential causes (see UF/IFAS Fact Sheet FA-55 Submission of Fish for Diagnostic Evaluation). Record-keeping is essential for good recirculating system and fish health management.

\section{Biosecurity}

Biosecurity has been discussed extensively in Parts 1 and 2 of this series (recommended reading). Biosecurity protocols are intended to maintain the "security" of a facility (i.e., prevent entry of, or reduce overall numbers prior to entry) with respect to certain disease-causing organisms (parasites, bacteria, viruses, and fungi) that may not be present in a particular system.

\section{Different Levels of Biosecurity}

Although it is important that all aquaculturists understand the concepts involved, different levels of biosecurity will be applicable depending upon the purpose of the system and the fish, the species, stocking densities, frequency of movement of animals into or out of the system, the economics involved, the potential impact of introduced pathogens, and other factors. For example, the biosecurity protocols of a fish production facility, involved with breeding and growout and with limited movement of fish onto the facility, will differ from a fish wholesale operation, that has several shipments of fish brought in each week from different suppliers. Both of these situations will differ even more from a public aquarium with long-term resident populations of fish.

In the production facility, introduction of a virus, bacterium, parasite or fungus, not already present on the facility, will have greater overall impact than in a wholesale operation, especially if specific pathogens of concern exist for the species raised. Compared with a wholesale facility, the number of new fish entering a production facility is limited, and younger, more susceptible life stages are present, therefore, 
stricter biosecurity protocols may be reasonable and necessary. New broodstock (from an outside source) may contain pathogens different from those already on the production facility, so quarantining these fish is a good idea and well worth the extra space, time, and money required.

On the other hand, a fish wholesaler has a more limited biosecurity program because the fish are not held at the facility for long periods of time, due to market demand. If a fish wholesaler was to attempt to keep up with market demand and to implement a biosecurity program to match that of a production facility, the costs would be prohibitive because a) the numbers and sources of new fish entering the facility weekly are much greater than in a production facility; b) these numbers would need to be increased even further to keep up with market demand, so far higher numbers of tanks and systems would be required for quarantine; c) the fish are stocked at higher densities, so greater disease problems would result during the quarantine period and, therefore, the associated medication costs would increase; and d) the labor for maintenance and upkeep of these additional tanks or systems would increase costs even further.

Quarantine protocols for public aquaria differ greatly from those used by producers or wholesalers. Systems at these public aquaria often contain many different species of fish, some of which have been present for a long time. Because these systems are set up for long-term display, and often have little water turnover, there is the potential that, over time, pathogens will reach high loads and be more easily transmitted from one fish to another. In addition, the display nature of these systems makes treatment undesirable on the short-term.

It is critical, then, for public aquaria staff to allow for extended periods of quarantine and adequate numbers of separate systems and tanks (to allow for complete isolation of different groups of fish). Making sure the fish are as "clean" as possible makes sense, and is well worth the labor and personnel required.

The differences briefly described above determine the extent to which biosecurity measures can be easily adapted and followed, as well as the extent to which different procedures are actually necessary. For assistance with development of biosecurity protocols, contact a fish health specialist.

\section{Quarantine}

Biosecurity involves following strict management protocols to prevent specific pathogens from entering a system, or reducing the numbers that do. A good understanding of pathogen reservoirs (as discussed in Part 2 of this series) is important. Quarantine, sanitation, and disinfection are all important components of biosecurity.

Quarantine (see Part 1 of this series), defined as the isolation of an organism or group of organisms to prevent the introduction or spread of infectious disease, is a standard procedure that is extremely important in aquaculture and aquatic systems. In practical terms, quarantine is a standard set of procedures that should be observed to prevent the introduction of certain pathogens, or disease, into a population of fish.

In certain situations, to avoid bringing specific diseases onto a facility, sampling and testing of a number of fish prior to transport may be required or recommended, to make sure the population will not bring with it an important disease.

Quarantine is an important tool of preventative medicine. Quarantine benefits both old and new populations. A new population of fish in quarantine has time to recuperate from previous stressors and diseases (if present). Quarantine enables the new population to acclimate to water conditions, nutritional programs, and general management regimes. It also allows the immune systems of the new population to return to normal before they are exposed to pathogens from the old (or resident) population. An old population, on the other hand, is protected from exposure to pathogens that the new population may be harboring or shedding because of previous stressors.

When possible, all quarantine protocols should be strictly adhered to (please refer to Part 1 of this series for more detail on quarantine protocols). If strict observation of quarantine is not possible, managers should follow as many of the following protocols as are practical: 
- if necessary, testing of a sample of fish prior to bringing them onto the facility

- all-in, all-out stocking

- isolation or separation from other populations for a period of time (depending upon the fish species, the diseases of concern, the system, the ultimate use of the fish, and any previous testing done, this period may last from 1-8 weeks)

- observation and diet adjustment

- sampling and treatment, if necessary

- reduction or elimination of infectious pathogens

If fish cannot be sacrificed, skin and gill biopsies may provide information on external parasites and fecal samples may provide information on internal parasites. However, if numbers allow, it is best to sacrifice a representative sample of fish and perform full necropsies on them, including microbiological cultures and virology.

The bottom line - any introduction of new fish into a system already containing fish should be done carefully to avoid transmission of pathogens.

Quarantine is recommended for all new fish prior to introduction into an established population or system, especially for valuable fish.

For valuable fish (e.g., high quality koi or important broodstock), one recommendation, after initial quarantine, is to place 1-3 fish from the new population together with 1-3 fish from the old population in a tank that is separated (or "off line") from other tanks. Observations of the mixed population for a week or two should indicate if disease transmission may occur.

\section{Sanitation and Disinfection}

Good sanitation and disinfection procedures reduce the numbers of disease-causing organisms present within a given system and prevent or reduce the spread of disease-causing organisms from one system to another.

\section{Recommended Sanitation and Disinfection Protocols}

In addition to those quarantine protocols listed in the previous section, some practical methods that will help prevent or reduce the pathogen load in a system include:

- Proper attention to food sources

1. be careful with live foods: although live or fresh foods can be a good source of nutrients, these may also be a source of pathogens

2. ensure proper storage(in a cool, dry location) and usage (follow manufacturers recommendations/expiration date) of manufactured feeds to prevent loss of nutrients and build up of pathogens or toxins

- Good overall system maintenance and cleanliness to reduce environments that will favor parasites

1. good husbandry (nutrition, water quality, social structure, habitat)

2. regular siphoning of excess organic matter from sumps and tanks

3. backwash of filters as needed to reduce organic loading

4. check air and water pumps and lines

5. flush sediment out of water lines as needed

6. maintain UV sterilizers (regular bulb changes, as per manufacturers recommendations; cleaning quartz sleeves) and ozone units (check generator and other components, monitor for levels in the system)

7. keep nets and other equipment off the floor

- Pull dead and moribund fish as soon as possible and dispose of appropriately 
- Avoid cross contamination of equipment or water from one system to another

- Use disinfectants for equipment including nets and footbaths (placed at strategic locations around the facility, e.g., at the entrance and exit of quarantine buildings, hatcheries, other recirculating system buildings)

- Check with a fish health or aquaculture specialist to determine which disinfectants are best for your situation (UF/IFAS Fact Sheet VM-87 Sanitation Practices for Aquaculture Facilities)

\section{Problem-Solving Approaches}

Strictly adhering to the principles of biosecurity and good husbandry management will prevent many disease outbreaks. However, problems that may lead to disease will arise even in the best-managed systems and a scientific and methodical approach will help determine the best course of action, reduce losses, and get the system and fish back to normal. Record-keeping is an important tool in this approach.

Problems may or may not result in diseased fish. The key to preventing disease and reducing losses is early detection of any abnormalities in the system or the fish. Early detection relies on daily monitoring of water quality, general system checks, and observing fish behavior, fish appearance, and mortalities. Working with an aquaculture or recirculating system specialist will help solve problems.

\section{Common Water Quality Issues}

Optimal water quality should be determined for the species being held as it may vary among species, life stages, or systems.

The following general guidelines in Table 1 highlight common problems with water quality that often contribute to disease.

\section{Diagnosing Problems}

Some early warning signs of disease in a population of fish include changes in behavior or appearance, reduced or absent feeding response, as well as increases in morbidity (sick fish) and mortality (deaths). It is strongly recommended that you read the UF/IFAS documents Circular 921 Introduction to Fish Health Management and Fact Sheet FA-55 Submission of Fish for Diagnostic Evaluation. Working with a fish health specialist to identify and solve disease problems is highly recommended. In many cases, two or more factors, such as changes in water quality, handling, parasites or bacteria, will have contributed to the disease outbreak, and each must be corrected.

Records of water quality and management actions should be reviewed for early warning and any problems should be corrected (see above table). Nutritional programs should be examined for completeness (this will vary depending upon the species requirements and life stage), and storage of feeds should be evaluated to ensure feeds are stored properly (cool temperatures, low humidity, and for minimal periods).

Fish should be evaluated, preferably with the assistance of a fish health specialist. Early warnings will include behavioral changes, lack of feeding, and any obvious external signs of disease (e.g., ulcerations, white spots, hemorrhages, or presence of fungi). A representative sample of sick fish should be sacrificed for necropsies. Necropsies should include examination of all tissues for appearance and presence of abnormalities; search for external and internal parasites; microbiological culture of pertinent organs; histopathology; and virology, if warranted. Any necessary treatments should then be based on findings from all pertinent tests.

\section{Summary}

Recirculating systems have been used in aquaculture for many years. Although they are believed by some to be state-of-the-art and a "silver bullet" that eliminates common diseases and problems seen in other aquaculture production systems, they have their own unique set of problems, require stringent management, and may not be applicable or practical for all species at this time.

Designs and components of systems continue to be upgraded and streamlined, but basic management principles remain unchanged. 


\begin{tabular}{|c|c|c|}
\hline The Problem & The Possible Cause(s) or Evidence & The Solution(s) \\
\hline $\begin{array}{l}\text { Low dissolved } \\
\text { oxygen levels }(<4 \\
\mathrm{mg} / \mathrm{L})\end{array}$ & $\begin{array}{l}\text { - inadequate aeration } \\
\text { - over stocking } \\
\text { - over feeding } \\
\text { - high levels of organic sediments or non-biofilter } \\
\text { bacteria in tanks or vats or filters } \\
\text { - inadequate water flow } \\
\text { - use of oxygen-consuming chemicals } \\
\text { (e.g., formalin) }\end{array}$ & $\begin{array}{l}\text { Determine all contributing factors and correct each one. For } \\
\text { example: } \\
\text { - improve aeration by using air stones, increasing water } \\
\text { turnover, or injecting oxygen } \\
\text { - remove fish to lower stocking density } \\
\text { - reduce food to correct over feeding } \\
\text { - backwash filters more frequently } \\
\text { - change out water more often to clean out excess detritus, } \\
\text { remove unwanted bacteria and remove oxygen-consuming } \\
\text { chemicals } \\
\text { - increase water flow if inadequate }\end{array}$ \\
\hline $\begin{array}{l}\text { Nitrate levels too } \\
\text { high (especially in } \\
\text { marine systems) }\end{array}$ & $\begin{array}{l}\text { - the system has been set up for some time } \\
\text { without significant water changes } \\
\text { - stocking or feeding rates are high resulting in } \\
\text { large amounts of ammonia being converted to } \\
\text { nitrite and, finally, nitrate } \\
\text { - the water source is high in nitrates }\end{array}$ & $\begin{array}{l}\text { - Perform water changes (if source water has less nitrate) } \\
\text { - reduce the bioload (decrease stocking rate, decrease rate } \\
\text { or amount of food) } \\
\text { - consider denitrification of the system (contact a recirculation } \\
\text { system specialist) }\end{array}$ \\
\hline $\begin{array}{l}\text { Sudden decrease in } \\
\text { alkalinity }\end{array}$ & $\begin{array}{l}\text { Similar causes as those for sudden decrease in } \\
\mathrm{pH} \text {. }\end{array}$ & $\begin{array}{l}\text { - add sodium bicarbonate (baking soda) until alkalinity range } \\
\text { is } 100-180 \mathrm{mg} / \mathrm{L}\end{array}$ \\
\hline $\begin{array}{l}\text { Supersaturation } \\
\text { (most commonly } \\
\text { associated with } \\
\text { nitrogen gas) }\end{array}$ & $\begin{array}{l}\text { - supersaturation of gases in source water } \\
\text { - leak in pump so that it is sucking in air } \\
\text { - bubbles present on the walls of the tank or vats, } \\
\text { in the water column, or on the body or fins of } \\
\text { fish }\end{array}$ & $\begin{array}{l}\text { - determine the source of supersaturation } \\
\text { check all pumps and pipes for leaks (commonly on the } \\
\text { suction side) and repair }\end{array}$ \\
\hline
\end{tabular}

Table 1. Diagnosing Problematic Issues with Water Quality

Preventative medicine is critical. Preventative

medicine includes proper attention to species biology, 
genetics, water quality, nutrition, system design, biosecurity (quarantine, sanitation, and disinfection) and overall management.

An understanding of common diseases is also important. Common infectious and non-infectious diseases will vary from one species to another.

Temperature will affect the immune status of the animals, as well as the growth and reproduction of pathogens (i.e., parasites, bacteria, fungi or viruses). Temperature will also determine the speed of the biofilter cycling process. Cooler water temperatures will slow down the growth of beneficial bacteria in the biofilter.

Knowledge of how treatment chemicals and antibiotics affect the system is also important. Their proper use in recirculating systems should be understood, and all relevant legal issues should be determined prior to their use. Work with a fish veterinarian or other fish health specialist on these issues and on proper diagnosis of diseases.

Consult with knowledgeable aquaculture specialists, experts on recirculating systems, and fish health specialists prior to starting a recirculating aquaculture venture. Such efforts will maximize the chances of success.

\section{Recommended Reading}

SRAC Publication No. 479b Columnaris

Disease. http://srac.tamu.edu/479bfs.pdf

UF/IFAS Circular 57 Streptococcal Infections of Fish. http://edis.ifas.ufl.edu/FA057

UF/IFAS Circular 84 Use of Antibiotics in Ornamental Fish Aquaculture. http://edis.ifas.ufl.edu/FA084

UF/IFAS Circular 120 Fish Health Management Considerations in Recirculating Aquaculture Systems - Part 1: Introduction and General Principles. http://edis.ifas.ufl.edu/FA099

UF/IFAS Circular 121 Fish Health Management Considerations in Recirculating Aquaculture Systems - Part 2: Pathogens. http://edis.ifas.ufl.edu/FA100
UF/IFAS Circular 716 Introduction to

Freshwater Fish Parasites.

http://edis.ifas.ufl.edu/FA041.

UF/IFAS Circular 919 Stress - Its Role in Fish Disease. http://edis.ifas.ufl.edu/FA005.

UF/IFAS Circular 920 Ichthyopthirius multifiliis (White Spot) Infections in Fish. http://edis.ifas.ufl.edu/FA006.

UF/IFAS Circular 921 Introduction to Fish Health Management. http://edis.ifas.ufl.edu/FA004.

UF/IFAS Fact Sheet FA-14 Aeromonas Infections. http://edis.ifas.ufl.edu/FA042.

UF/IFAS Fact Sheet FA-16 Ammonia. http://edis.ifas.ufl.edu/FA031.

UF/IFAS Fact Sheet FA-28 Mongenean Parasites of Fish. http://edis.ifas.ufl.edu/FA033.

UF/IFAS Fact Sheet FA-29 Introduction to Viral Diseases of Fish. http://edis.ifas.ufl.edu/FA034.

UF/IFAS Fact Sheet FA-31 Vibrio Infections of Fish. http://edis.ifas.ufl.edu/FA036.

UF/IFAS Fact Sheet FA-55 Submission of Fish for Diagnostic Evaluation. http://edis.ifas.ufl.edu/FA055.

UF/IFAS Fact Sheet FA-95 Molds in Fish Feeds and Aflatoxicosis. http://edis.ifas.ufl.edu/FA095.

UF/IFAS Fact Sheet VM-77 Use of Formalin to Control Fish Parasites.

http://edis.ifas.ufl.edu/VM061.

UF/IFAS Fact Sheet VM-86 Use of Salt in Aquaculture. http://edis.ifas.ufl.edu/VM007.

UF/IFAS Fact Sheet VM-87 Sanitation Practices for Aquaculture Facilities. http://edis.ifas.ufl.edu/AE081.

UF/IFAS Fact Sheet VM-96 Mycobacteriosis in Fish. http://edis.ifas.ufl.edu/VM055.

UF/IFAS Fact Sheet VM-97 Fungal Diseases of Fish. http://edis.ifas.ufl.edu/VM033. 
UF/IFAS Fact Sheet VM-142 Spring Viremia of Carp. http://edis.ifas.ufl.edu/VM106

\section{References and Further Reading}

Bedell G.W. 1971. Eradicating Ceratomyxa shasta from infected water by chlorination and ultraviolet irradiation. Progressive Fish-Culturist 33: 51-54.

Collins M.T., J.B. Gratzek, D.L. Dawe and T.G. Nemetz. 1975. Effects of parasiticides on nitrification. Journal of the Fisheries Research Board of Canada 32: 2033-2037.

Collins M.T., J.B. Gratzek, D.L. Dawe and T.G. Nemetz. 1976. Effects of antibacterial agents on nitrification in an aquatic recirculating system. Journal of the Fisheries Research Board of Canada 33: 215-218.

Hach Company. 2002. Water Analysis Handbook, Fourth edition. Hach Company, Loveland, CO. $1260 \mathrm{pp}$.

Hoffman G.L. 1974. Disinfection of contaminated water by ultraviolet irradiation with emphasis on whirling disease (Myxosoma cerebralis) and its effect on fish. Transactions of the American Fisheries Society 103: 541-550.

Kasai H., M. Yoshimizu and Y. Ezura. 2002. Disinfection of water for aquaculture. Fisheries Science, Volume 68, Supplement I, pp. 821-824. Blackwell Publishing, Oxford, UK.

Levine G. and T.L. Meade. 1976. The effects of disease treatment on nitrification in closed system aquaculture. Proceedings from the $7^{\text {th }}$ Annual Meeting of the World Mariculture Society, J.W. Avault Jr. (editor), pp 483-493. World Mariculture Society, Louisiana State University, Baton Rouge, LA.

Miocevic I., J. Smith, L. Owens and R. Speare. 1993. Ultraviolet sterilization of model viruses important to finfish aquaculture in Australia. Australian Veterinary Journal 70: 25-27.

Nagy R. 1964. Application and measurement of ultraviolet irradiation. American Industrial Hygiene Association Journal 25: 274-281.
National Research Council. 1993. Nutrient Requirements of Fish (Committee on Animal Nutrition, Board on Agriculture). National Academy Press, Washington, DC. 114 pp.

Normandeau D.A. 1968. Progress Report, Project F-14-R-3, State of New Hampshire (Mimeo).

Rodriguez J. and T.R. Gregg. 1993. Considerations for the Use of Ultraviolet in Fish Culture in Techniques for Modern Aquaculture: Proceedings of an Aquaculture Engineering Conference 21-23 June 1993, p 482. American Society of Agricultural Engineers, St. Joseph, MI.

Spotte S. 1979. Fish and Invertebrate Culture: Water Management in Closed Systems, Second edition. John Wiley and Sons Inc., New York, NY. $179 \mathrm{pp}$.

Vlasenko M.I. 1969. Ultraviolet rays as a method for the control of disease of fish eggs and young fishes. Journal of Ichthyology (formerly, Problems of Ichthyology) 9: 697-705.

Yoshimizu M., H. Takisawa and T. Kimura. 1986. UV susceptibility of some fish pathogenic viruses. Fish Pathology 21: 47-52. 